MARKETING AND BRANDING
RESEARCH $\begin{gathered}\text { INDUSTRIAL } \\ \text { MANAGEMENT } \\ \text { INSTITUTE }\end{gathered}$

\title{
New world, new economics
}

\author{
Manijeh Aliakbarian
}

Master of Science in Economics, Eastern Mediterranean University (EMU), North of Cyprus

\begin{tabular}{|c|c|}
\hline & ABSTRACT \\
\hline $\begin{array}{l}\text { Keywords: } \\
\text { World Economics, } \\
\text { Innovation, Investment } \\
\text { on R\&D, Optimize } \\
\text { Benefiting, Facilitating } \\
\text { in Trading, Standard of } \\
\text { Living }\end{array}$ & $\begin{array}{l}\text { World economy has changed since the } 20^{\text {th }} \text { century. Although changes in the world happenec } \\
\text { in all scientific areas, but this survey is focused on economics only. In the present study, for } \\
\text { illuminating the new picture of the new world on economics and the gaps between the } \\
\text { developed and developing countries, panel data model and time series are used for analyzing } \\
\text { the macroeconomics of sample countries. The efficiency of independent variables on } \\
\text { dependent variable GDP is illustrated by data test that analyzes the relationship between the } \\
\text { variables. The results revealed that the new world is based on innovation. Therefore, in mos } \\
\text { countries investing on R\&D sector is increased. This rising caused employing educatec } \\
\text { talents who could reveal the new ways of optimizing the benefits of the resources in the } \\
\text { world that increases development, decreases poverty, and increases standard of living and } \\
\text { welfare. This might be effective on finding new ways of relation between countries and } \\
\text { facilitate trading. Such studies on ways of reduction of the production costs and decreasing } \\
\text { tariff is important in simplifying the market potentials productivities and finding demands } \\
\text { through the world to create new vantages. Although restrictions in macro and micrc } \\
\text { economics is occurred in some countries, there are examples that by finding the solution } \\
\text { could increase their development rank as well as standard of living and poverty reduction. }\end{array}$ \\
\hline
\end{tabular}

(C)AIMI Journals

\section{Introduction}

As the role of existence of demand in producing commodity is the most important issue in economy, countries were always keen on finding new ways and methods for improving market for manufactured goods. Therefore, new techniques are implied by governments during the ages for finding new markets to sell their commodity and to optimize the benefiting of natural resources. By international cooperation to decrease the cost of 
production and facilitate trading, agreements and relations between partners and governments become important to find solution for exploitation of new sources. These attempts need research and require the use of new talents and innovation of new techniques. For this reason, some companies invest on research and allocate specific budget to establish special section for research and development (R\&D). Though, innovation not only depends on spending money for R\&D (Jaruzelski, Staack, \& Goehle, 2014), it is also about the skillful people you have and how you manage them and it also refers to employers' capacity to use this knowledge.

Thus, new methods such as supply chain product are applied for program developing in industry and product section. Following this, in trading with facilitating the import, export, cooperation, and transaction, improvement in the relationship between countries can be achieved. In some cases, decreasing the tariff of import with having a rule tries to encourage the local producers to improve the quality of their goods.

In recent years, there were many world agreements such as World Trade Organization (WTO), Organization for Economic Co-Operation and Development (OECD), and Global Value Chain (GVC) that will grow and develop in dynamic regions of the world (Low, 2013); International Monetary Fund (IMF), World Bank, the European Union (EU), Trans-Pacific Partnership (TPP) that the U.S. and 11 Pacific countries had a free trade agreement and it is one of the most important world contract transaction which is about circumstance of benefiting the resources of Pacific Ocean; Trans-Atlantic Trade and Investment Partnership (TTIP) also had free trade agreement between U.S. and EU. All these transactions revealed that there are strong relationships between innovations, investing in R\&D, and GDP growth. OECD countries by investing on R\&D and innovation could make large markets around the globe.

The other trend in the world today is about different wages of employees which move the employees to other countries or investors because of lower wages. The other important agreement refers to the North American Free Trade Agreement (NAFTA) which is about employment and exchanging employees between Canada, Mexico, and the United States. Following this, a recent trade agreement between Korea, Colombia, and Panama send jobs overseas and gets benefits of trade between narrow classes of wealthy investors. Investor-toState Dispute Settlement (ISDS) is another agreement that is about foreign investment's regulations. There is an another cooperation between Brazil, Russia, India, and China (BRICs) and sometimes South Africa and Mexico that leads the main partners to grow faster than the other countries and reshapes the global economy and international polices. They share international management rules and change the structure of production and trade (Brookings Global Experts, 2007). As in South Asia or Africa, there are some limitations about education (Brookings Global Experts, 2007); therefore, they could not participate in economic and social activities. Thus, improving knowledge and finding new ways of corporation and innovation to find the effective ways for new opportunity in the global or individual business model (Brookings Global Experts, 2007) is very necessary.

The role of research and education in some countries is of great importance. To this end, the last noble prize winner in the economic 2015 was “Angus Deaton” and his new theory was about consumption, poverty and welfare. He believes that consumption has a 
fundamental role in human welfare. Distribution of consumption determined the poverty in society's economy and as consumption determined saving and investing and demanded analysis, it is very natural that research on consumption is the center of research through the last century (Deaton, 2015). The 2014 winner of noble prize was “Jean Tirol” whose finding was about market power and regulation (Tirole, 2014). He showed that how decreasing the cost of production, finding demand, and selling manufactured goods into the market are effective.

In an observation for the Uzawa-Lucas model it was shown that when education rises, the economic growth rate rises as well (Greiner, Semmler, \& Gong, 2005). The differences between the wages depends on the rate of employees' knowledge and on the skilled and unskilled labor that effects on production and subsequently on economic growth. As resources scarcity, there are many projects holding in the world for using the renewable local resources which caused the growth of innovative private sectors and NGOs (Brookings Global Experts, 2007) such as China as a successful country with global supply chain product and India with a growing strategy on domestic consumption and investment (Brookings Global Experts, 2007) that has success in exporting high skilled knowledge and industries such as software programs.

Improving the general knowledge in the world has direct and indirect effects on economics. There are many innovations that facilitated the relation between people and virtual world like Internet, IPad, telecommunication, and robots that let the consumers to improve their knowledge about the market and is known as electronic revolution. These achievements are about research in domains.

In finance imbalances, the account of countries reflects the gaps between the save domestically and invests (Brookings Global Experts, 2007). U.S. in 2004 absorb 75\% of surpluses of China, Japan, Germany, and other countries. The other imbalances refer to crediting a country's lending or borrowing system. Some countries like China would unlock a broader move of currency with Asian currencies (Brookings Global Experts, 2007). Thus, innovating the new way for global healthy financing (Brookings Global Experts, 2007) could facilitate the implementation of methods for financial corporation between countries.

Poverty and standard of living are the other global issue; more than half of people around the world live under poverty line (Brookings Global Experts, 2007) and need foods and fresh water whereas few countries in the world live higher than standard. This gap and difficulty could be solved with corporation between countries in healthy relationship without exploitation.

The new international trade cooperation is supply chain product (Elms \& Low, 2013); in this shape of relationship every country which has rich natural resources export it to other countries and import the commodity which is needed for their industry and general consumption. This kind of relationship is a multinational commercial between the countries. Nowadays, products comprise inputs from different countries. Following this, sometimes the components of a product import from various countries and assemble and install in one country. Being a part of this supply chain depends on the capacity of partners in different areas of beneficiary, whether it is about resources or manufactures such as import or export 
functions or value adding. With this kind of international relation, global economics is transformed.

As a result, significant progress can be seen in information, communication, transport technologies, and international production which is resulted by innovation and research that effects economics in total.

\section{Results}

In this section the growth rate of 5 countries (GDP) and relation between growth rate and spending budget for R\&D are compared. Table 1 shows the GDP deflator.

Table 1

GDP Deflator (Base Year Varies by Country)

\begin{tabular}{|c|c|c|c|c|c|c|c|c|c|c|c|}
\hline & 2000 & 2006 & 2007 & 2008 & 2009 & 2010 & 2011 & 2012 & 2013 & 2014 & 2015 \\
\hline \multicolumn{12}{|l|}{ American } \\
\hline U.S. & 80.9 & 93.7 & 96.2 & 98 & 98.8 & 100 & 102.1 & 103.9 & 105.6 & 107.4 & 108.5 \\
\hline \multicolumn{12}{|l|}{ Asia } \\
\hline China & 100 & 121.5 & 131.0 & 141.3 & 141.1 & 150.9 & 163.2 & 167.1 & 170.8 & 172.2 & 171.4 \\
\hline India & 54.3 & 70.8 & 75.6 & 82.2 & 87.2 & 95.0 & 100 & 107.9 & 174.6 & 178.3 & 119.5 \\
\hline Japan & 114 & 105 & 104 & 102.7 & 102.2 & 100 & 98.1 & 97.2 & 96.7 & 98.3 & 100.3 \\
\hline \multicolumn{12}{|l|}{ Europe } \\
\hline Germany & 89.7 & 95.1 & 96.7 & 97.5 & 99.2 & 100 & 101.1 & 102.6 & 104.7 & 106.6 & 108.7 \\
\hline
\end{tabular}

Source: World Development Indicators "World Bank”

Figure 1 presents the GDP deflator in US, China, India, Japan, and Germany.

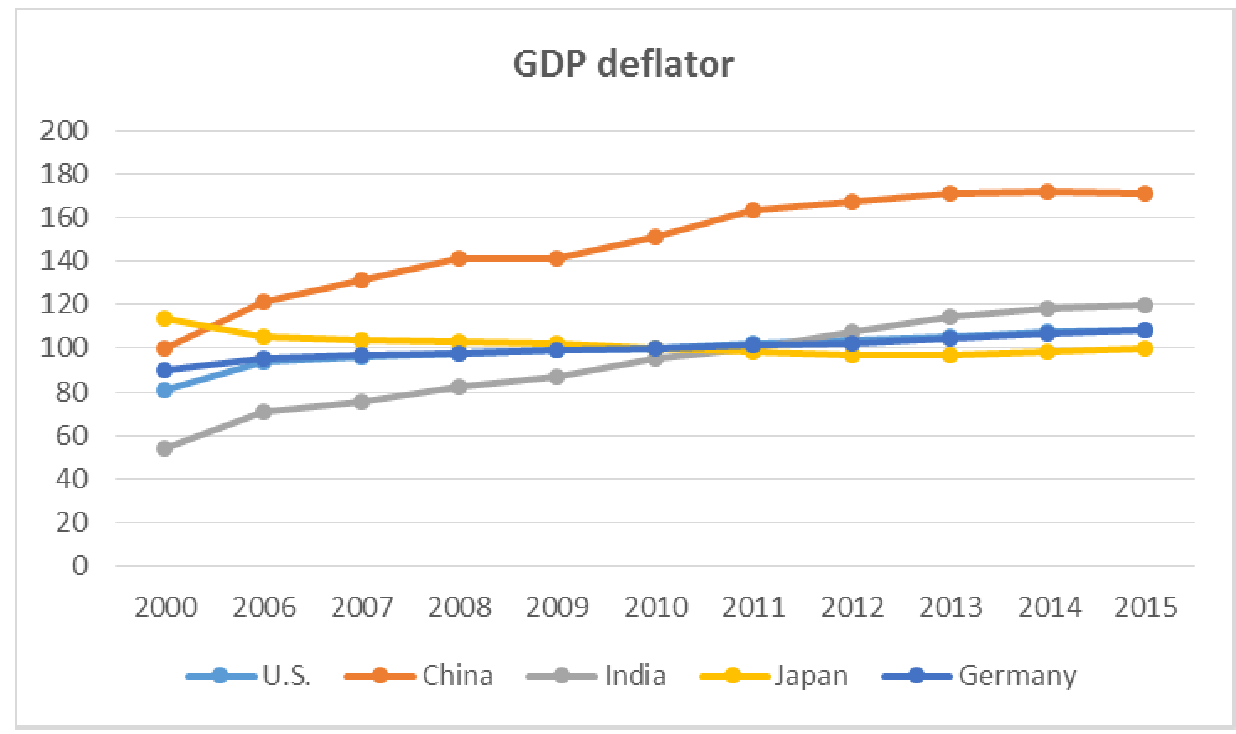

Figure 1. GDP deflator in US, China, India, Japan, and Germany

Table 2 exhibits the share of total global R\&D spending. 
Table 2

Share of Total Global R\&D Spending

\begin{tabular}{|c|c|c|c|}
\hline & 2012 & 2013 & 2014 \\
\hline American & $34.5 \%$ & $34.0 \%$ & $33.9 \%$ \\
\hline U.S & $32 \%$ & $31.4 \%$ & $31.1 \%$ \\
\hline Asia & $37 \%$ & $38.3 \%$ & $39.1 \%$ \\
\hline China & $15.3 \%$ & $16.5 \%$ & $17.5 \%$ \\
\hline India & $2.7 \%$ & $2.7 \%$ & $2.7 \%$ \\
\hline Japan & $10.5 \%$ & $10.5 \%$ & $10.2 \%$ \\
\hline Europe & $23.1 \%$ & $22.4 \%$ & $21.7 \%$ \\
\hline Germany & $6.1 \%$ & $5.9 \%$ & $5.7 \%$ \\
\hline Rest of World & $5.4 \%$ & $5.3 \%$ & $5.3 \%$ \\
\hline
\end{tabular}

Source: Battle R\&D Magazine

Figure 2 clearly represents the share of total global R\&D spending during 2012-2014 in US, China, Japan, India, and Germany.

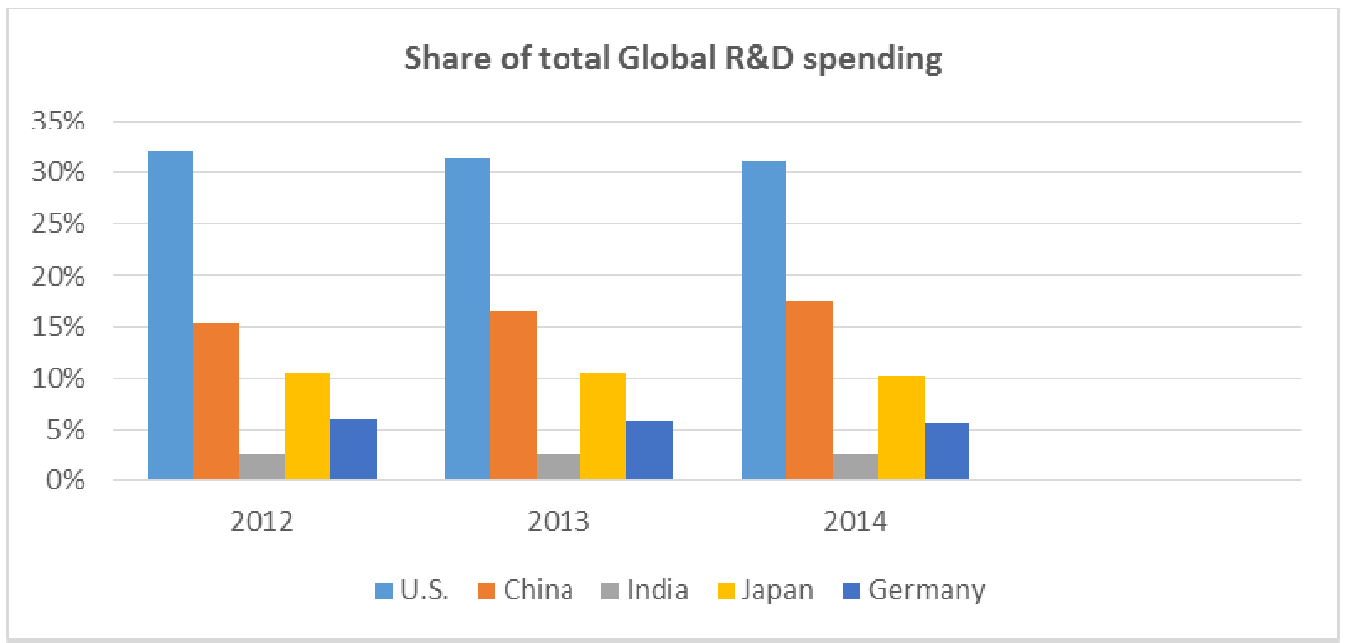

Figure 2. Share of total global R\&D spending during 2012-2014 in US, China, Japan, India, and Germany

Table 3 shows the total investment in R\&D.

Table 3

Total Investments in $R \& D$ (As a Percentage of GDP)

\begin{tabular}{clll}
\hline & 2012 & 2013 & 2014 \\
\hline Americas & $2.5 \%$ & $2.4 \%$ & $2.5 \%$ \\
Asia & $1.8 \%$ & $1.9 \%$ & $1.9 \%$ \\
Europe & $1.9 \%$ & $1.9 \%$ & $1.8 \%$ \\
Rest of world & $0.9 \%$ & $0.9 \%$ & $0.9 \%$ \\
\hline
\end{tabular}

Source: Battle R\&D Magazine

Figure 3 illustrates investing in R\&D as a percentage of GDP during 2012-2014 in America, Asia, Europe, and rest of the world. 


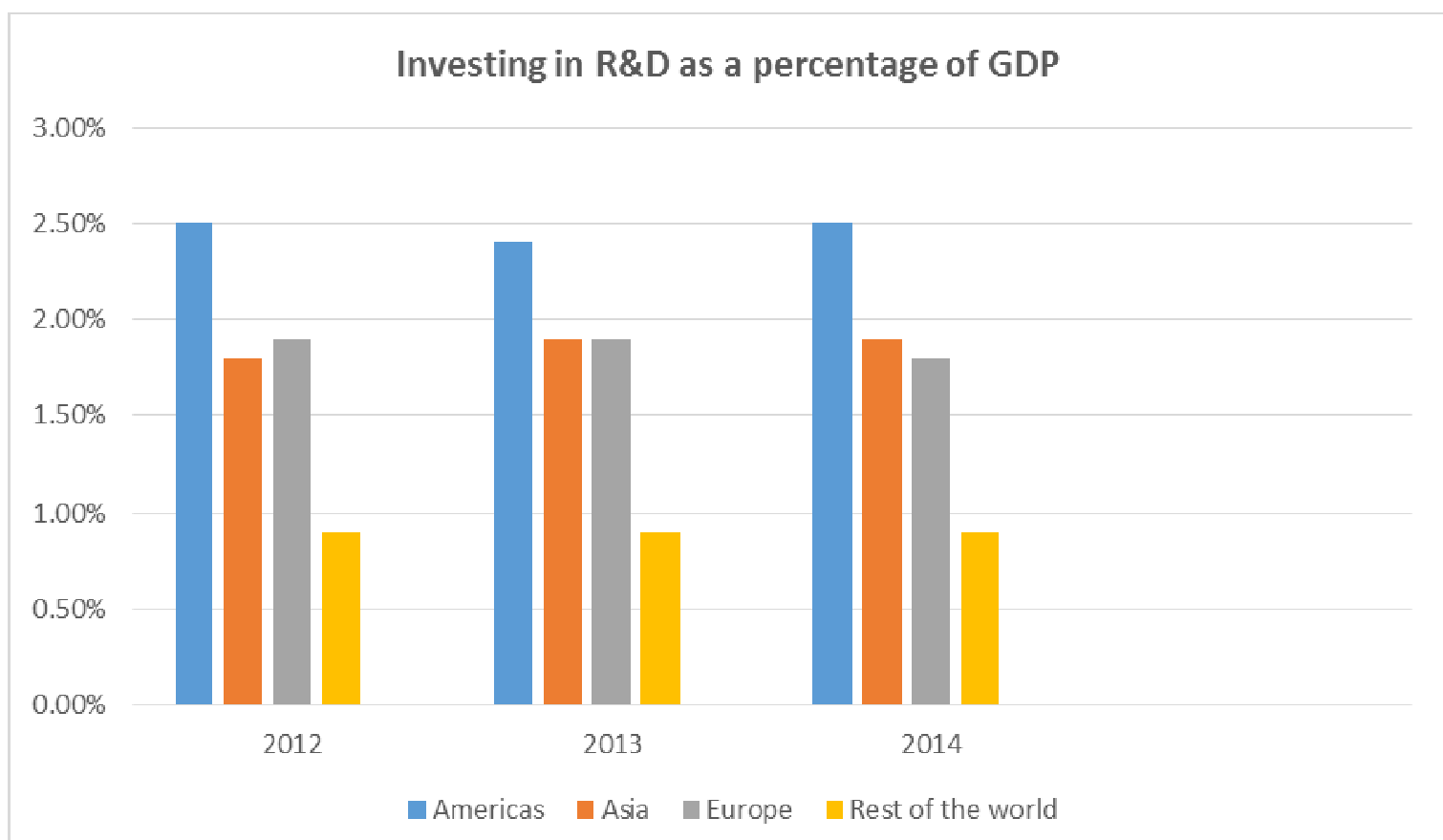

Figure 3. Investing in R\&D as a percentage of GDP during 2012-2014 in America, Asia, Europe, and rest of the world

According to Table 3 and Figure 3 America's invest for R\&D was more in 2012, 2013, and 2014 in comparison with the other countries and Europe after US and Asia has the third rate. Rest of the world has the less percentages which shows the low investment on research and development in other countries. Although just the investment for research could not be a measure for development, it could be one of the most important indicators for economic growth. Spending for R\&D should be accompanied with using and managing budget for various economic sectors. By looking at tables as a whole, it can be concluded that the more developed countries utilized more research.

\section{India}

After comparison between the relation of investment on research and development and economic growth in the world, India, as a unique country, was chosen for data analysis to reveal how this country with this vast dimension of region, population, and poverty could be the third country from the point of economic growth. Today, if India could decrease poverty and increase economic growth, it is a result of its superb infrastructure and internal efforts.

Table 4 and Figure 4 present GDP growth and GDP growth in India during 1990-2015, respectively.

Table 4

GDP Growth

\begin{tabular}{|c|c|c|c|c|c|c|c|c|c|c|c|c|}
\hline & 1990 & 2000 & 2006 & 2007 & 2008 & 2009 & 2010 & 2011 & 2012 & 2013 & 2014 & 2015 \\
\hline India & 5.5 & 3.8 & 9.3 & 8.6 & 3.9 & 8.5 & 10.3 & 6.6 & 5.6 & 6.6 & 7.2 & 7.6 \\
\hline
\end{tabular}

Source: World Development Indicators 


\section{GDP growth in India}

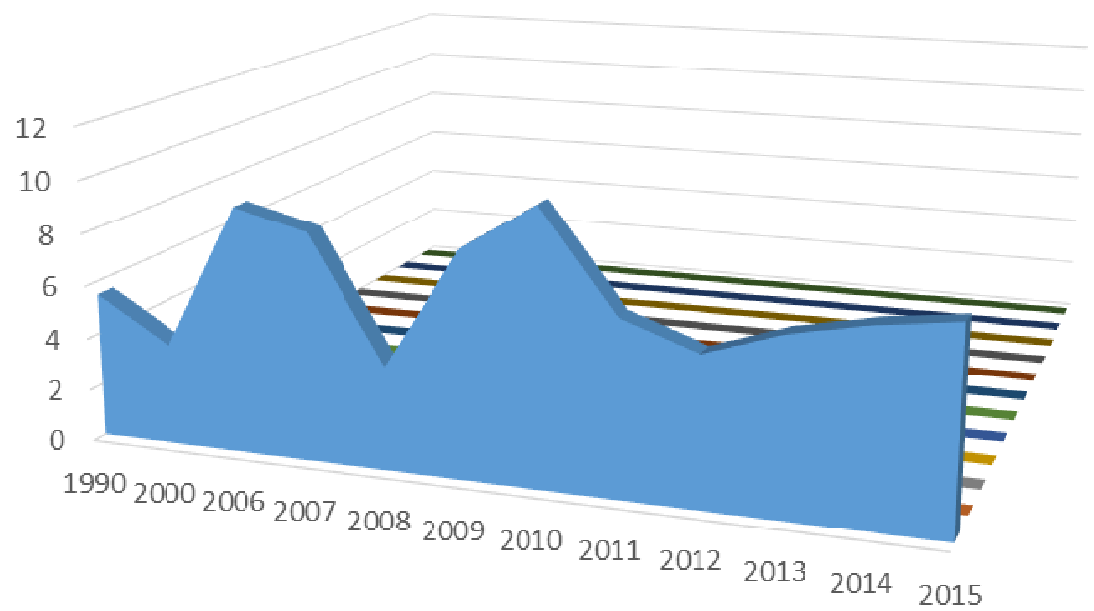

Figure 4. GDP growth in India during 1990-2015

As we see in Table 4 and Figure 4, GDP growth in 2010 was at the highest point of 10.3 and in 2000 was 3.8 which is the lowest. Table 5 represents research and development expenditure.

Table 5

Research and Development Expenditure (\%of GDP)

\begin{tabular}{ccccccccc}
\hline & $2001-2005$ & 2006 & 2007 & 2008 & 2009 & 2010 & 2011 \\
\hline India & 0.7 & 0.8 & 0.8 & 0.8 & 0.8 & 0.8 & 0.8
\end{tabular}

Source: World Data Bank- World Development Indicator

Figure 5 shows R\&D expenditure percentages of GDP in India during 2001-2011.

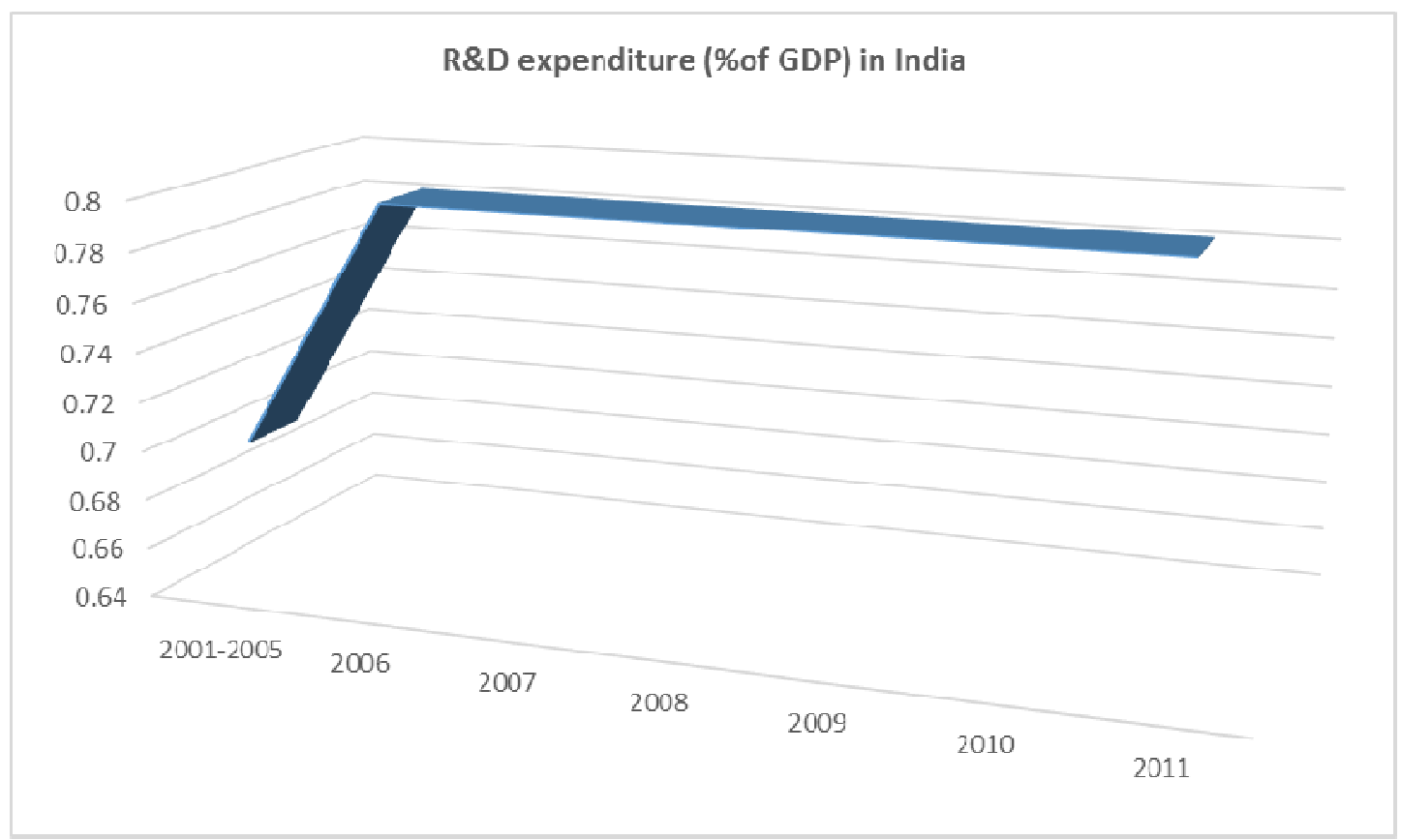

Figure 5. R\&D expenditure percentages of GDP in India during 2001-2011 
Percentages of GDP expenditure for R\&D in India were almost constant during 20062011 and it is $0.8 \%$ whereas it was $0.7 \%$ GDP during 2001-2005.

The percentages of GDP PPP for India to spend for research and development in 2011 was $0.82 \%$ and in 2015 , it was $0.85 \%$; to this end, India in year 2011 was the $7^{\text {th }}$ country in the world and it was the $6^{\text {th }}$ in 2015.

Table 6 and Figure 6 show research and development in India and percentage of GDP PPP in India during 2011-2015, respectively.

Table 6

Research and Development in India

\begin{tabular}{ccc}
\hline \% of GDP PPP & Year & Countries \\
\hline $0.82 \%$ & 2011 & 7 th \\
$0.85 \%$ & 2015 & 6 th \\
\hline
\end{tabular}

Source: Percentages of people below poverty line, 2012

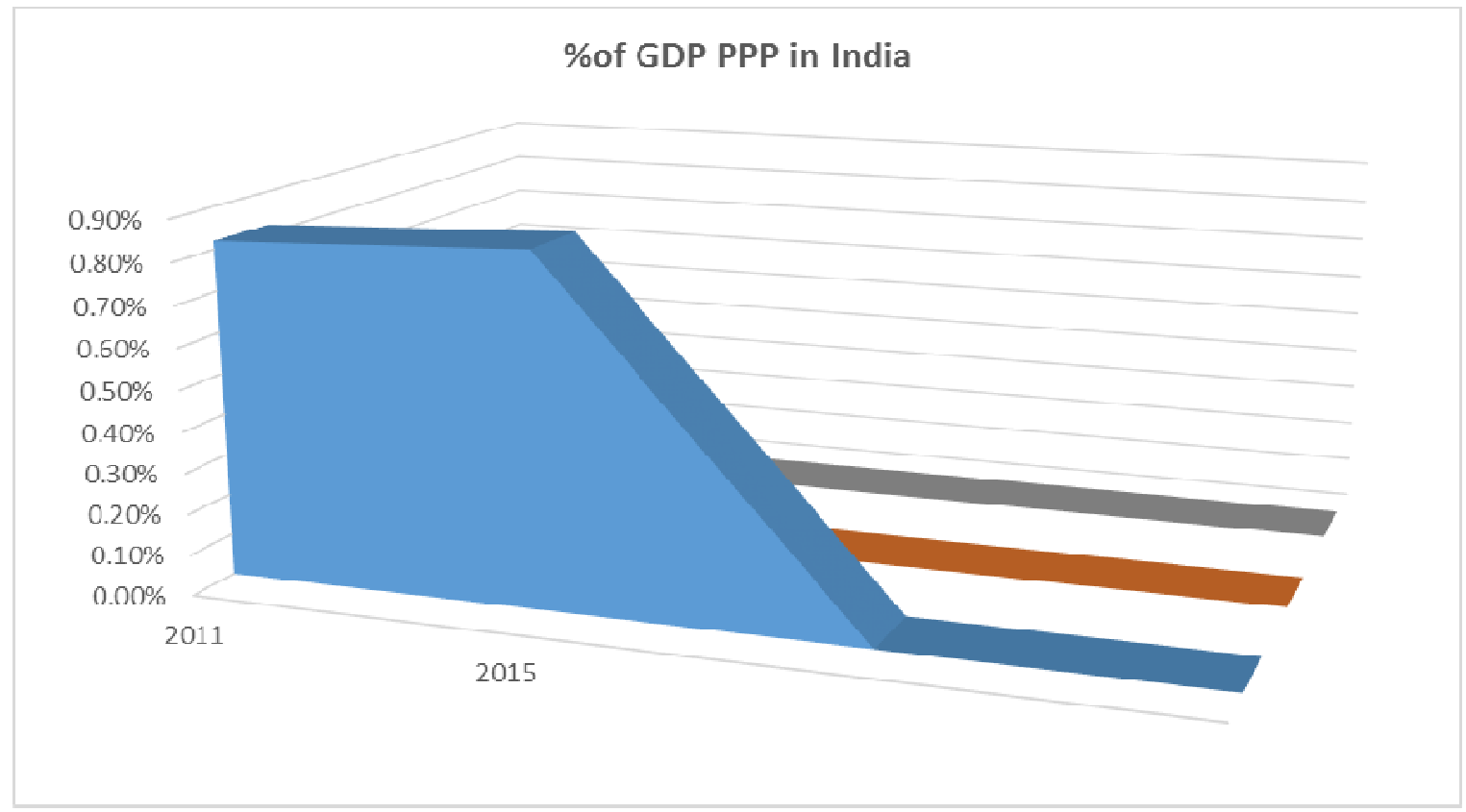

Figure 6. Percentage of GDP PPP in India during 2011-2015

India could increase the expenditure for research and development in 2011 from $0.82 \%$ to $0.85 \%$ and in 2015 , it could increase the rank in the world from $7^{\text {th }}$ to $6^{\text {th }}$. This rises in R\&D could be one of the reasons for economic growth in India. Table 7 indicates high-technology exports (current million U.S. \$).

Table 7

High-Technology Exports (Current Million U.S. \$)

\begin{tabular}{|c|c|c|c|c|c|c|c|c|c|c|c|c|c|c|c|}
\hline & 2001 & 2002 & 2003 & 2004 & 2005 & 2006 & 2007 & 2008 & 2009 & 2010 & 2011 & 2012 & 2013 & 2014 & 2015 \\
\hline India & 2287 & 2354 & 2710 & 3356 & 4139 & 4876 & 5998 & 7738 & 10728 & 10087 & 12871 & 12434 & 16693 & 17316 & 13751 \\
\hline
\end{tabular}

Source: World Data Bank-World Development Indicators

Figure 7 illustrates the rate of high technology export in India by million US dollar during 2001-2015. 


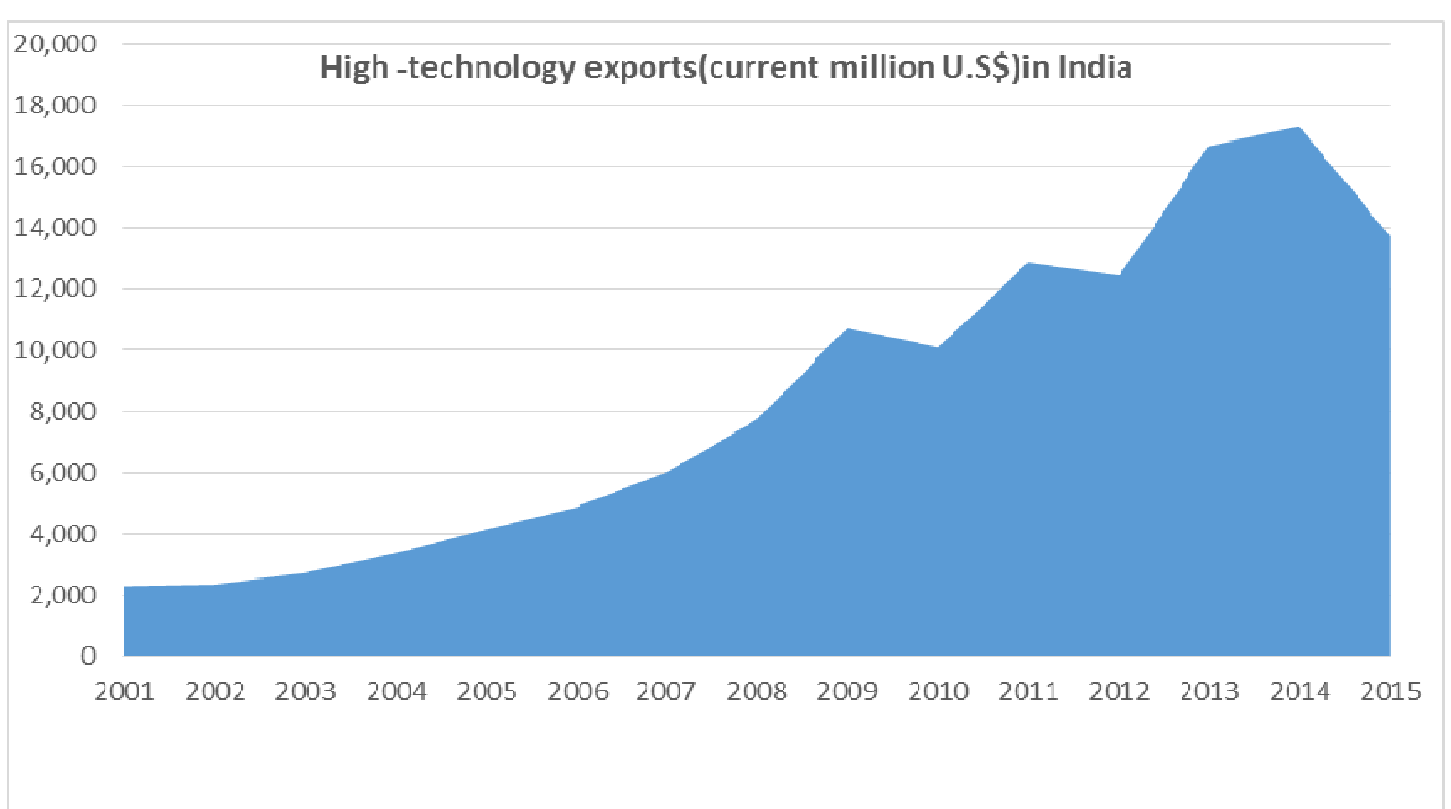

Figure 7. Rate of high technology export in India by million US dollar during 2001-2015

High-technology export in India during 2001-2014 grows, until 2014 that reaches the highest range of 17316 million U.S. \$ and then it declined to 13751 million dollars in 2015. In general, India's High-technology export trend increased during 2001-2014. Table 8 exhibits high-technology exports (\% of manufactured exports).

Table 8

High-Technology Exports (\% of Manufactured Exports)

\begin{tabular}{|c|c|c|c|c|c|c|c|c|c|c|c|c|c|c|c|}
\hline & 00 & 00 & 2003 & 2004 & 2005 & 2006 & 2007 & 2008 & 2009 & 2010 & 2011 & 2012 & 2013 & 2014 & 2015 \\
\hline Idic & 7.0 & 6.2 & 5.9 & 6.0 & 5.8 & 6.1 & 6.4 & 6.8 & 9.1 & 7.2 & 6.9 & 6.6 & 8.1 & 8.6 & 75 \\
\hline
\end{tabular}

Source: World Data Bank-World Development Indicators

Figure 8 shows the percentage of high technology exports of manufactured exports in India during 2001-2015.

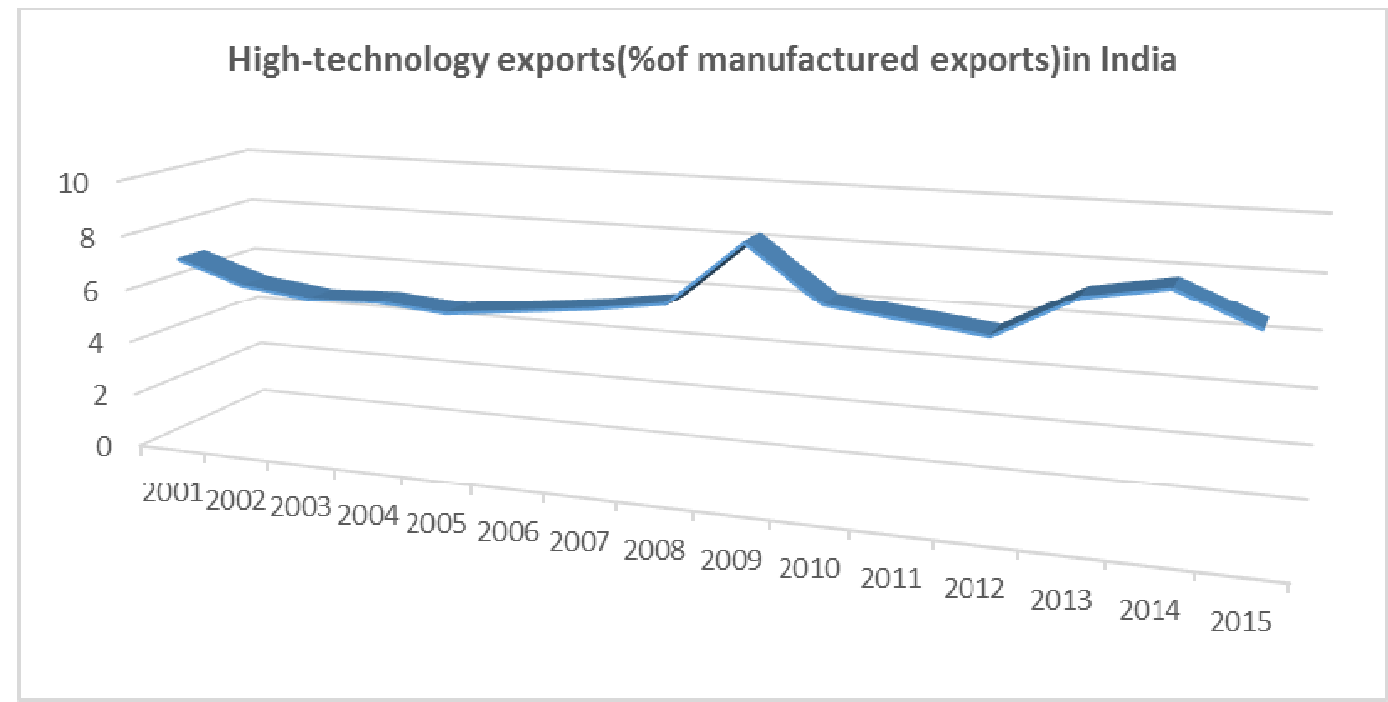

Figure 8. Percentage of high technology exports of manufactured exports in India during 2001-2015 
High-technology percentages of manufacture exports in India fluctuated during 20012015. The highest percentage was $9.1 \%$ in 2009 and the lowest was 5.8\% in 2005. In spite of fluctuation, India could enhance relationship between industry and research and instructed a good framework. Subsequently, it has a well growth trend in economy. Table 9 represents the poverty head count ratio at national poverty.

Table 9

Poverty Head Count Ratio at National Poverty

\begin{tabular}{ccccc}
\hline & 1993 & 2004 & 2009 & 2011 \\
\hline India & 45.3 & 37.2 & 29.8 & 21.9 \\
\hline
\end{tabular}

Source: World Data Bank

In India the percentages of people below poverty line in year 2012 was 21.92\% (Percentages of people below poverty line, 2012) and during the years, the poverty in India declined. Figure 9 depicts the poverty ratio percent in India during 1993-2011.

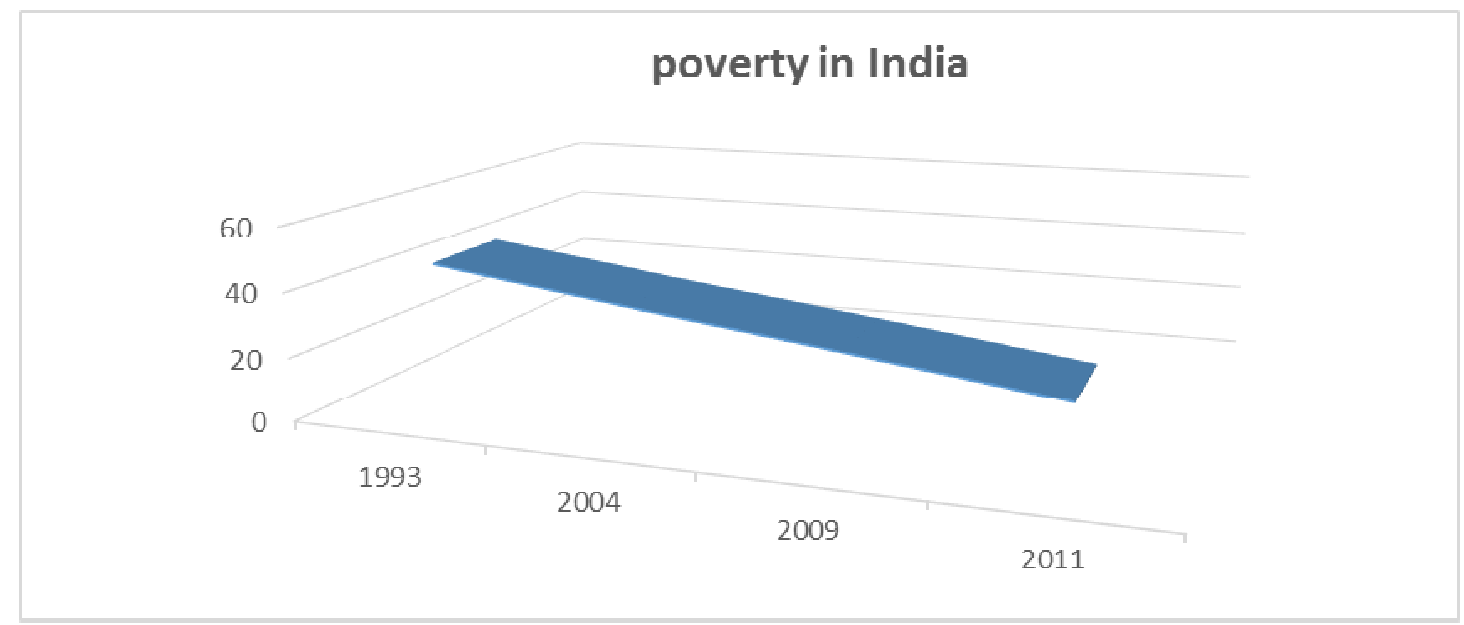

Figure 9. Poverty ratio percent in India during 1993-2011

Table 10 and Figure 10 show GINI index and GINI index in India during 1994-2011, respectively.

Table 10

GINI Index*

\begin{tabular}{ccccccc}
\hline & 1994 & 2004 & 2005 & 2009 & 2010 & 2011 \\
\hline India & 30.82 & 33.38 & 33.38 & 33.90 & 33.90 & 33.60 \\
\hline
\end{tabular}

Source: Data Base World Bank Estimate

*The GINI Index is a measurement of the income distribution. 


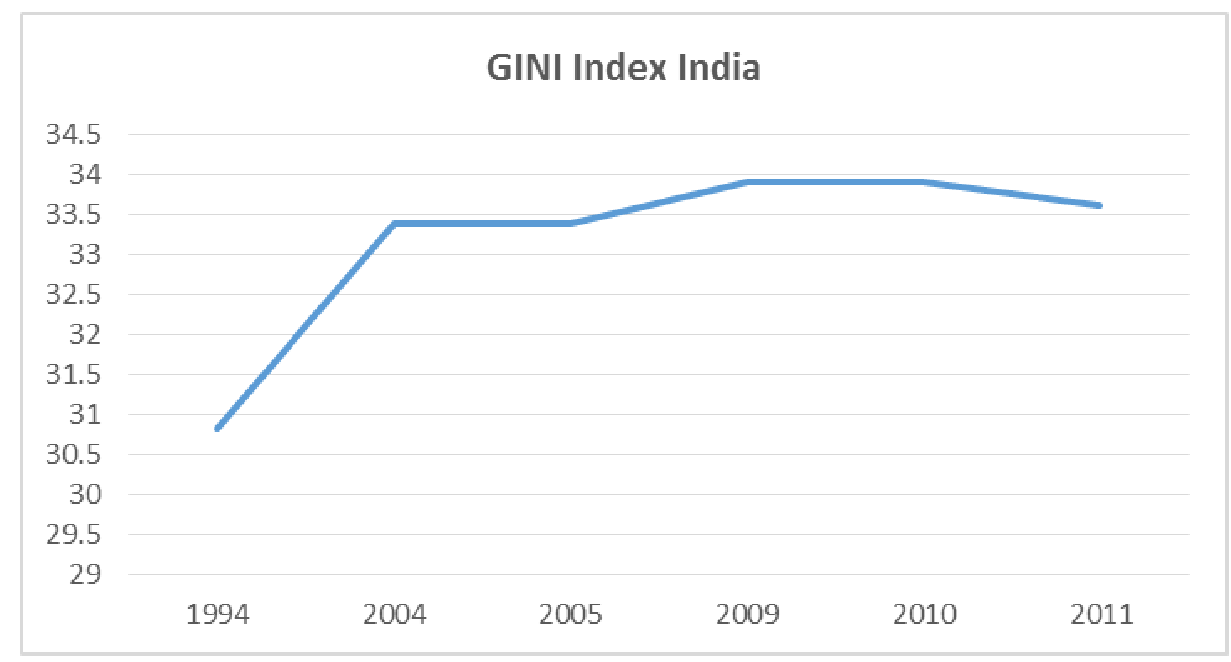

Figure 10. GINI index in India during 1994-2011

The distribution of income in India based on "World Bank" data is medium.

\section{Analysis of Economics Growth of India by Econometrics}

With Panel Data Model and time series between the years 2000-2011, the coefficient of ten independent variables on dependent variable GDP was estimated and they are clearly indicated in Table 11.

Table 11

\begin{tabular}{|c|c|c|c|c|c|c|c|c|c|c|c|}
\hline Year & GDP & Population & Investment & Export & Import & Agriculture & FDI* & Industry & Inflation & $\mathrm{R} \& \mathrm{D}$ & Unemployed \\
\hline 2000 & 477 & 1.05 & 115.7 & 61.05 & 65.34 & 109.71 & 3.58 & 124.02 & 4.01 & 3.54 & 4.3 \\
\hline 2001 & 494 & 1.07 & 119.7 & 60.76 & 65.20 & 113.12 & 5.12 & 123.99 & 3.68 & 3.57 & 4 \\
\hline 2002 & 524 & 1.09 & 129.69 & 73.36 & 78.6 & 108.46 & 5.20 & 137.28 & 4.39 & 3.73 & 4.3 \\
\hline 2003 & 618 & 1.10 & 165.8 & 90.84 & 95.17 & 127.92 & 3.68 & 160.68 & 3.81 & 4.36 & 3.9 \\
\hline 2004 & 722 & 1.12 & 236.96 & 127.07 & 139.34 & 137.18 & 5.42 & 201.43 & 3.77 & 5.37 & 3.9 \\
\hline 2005 & 834 & 1.14 & 288.98 & 160.96 & 183.48 & 156.79 & 7.26 & 234.35 & 4.25 & 6.75 & 4.4 \\
\hline 2006 & 949 & 1.16 & 338.4 & 200.23 & 229.65 & 173.66 & 20.02 & 273.31 & 6.15 & 7.56 & 4.3 \\
\hline 2007 & 1239 & 1.18 & 472.18 & 252.75 & 302.316 & 226.73 & 25.22 & 359.31 & 6.37 & 9.8 & 3.7 \\
\hline 2008 & 1224 & 1.19 & 419.95 & 288.86 & 351.28 & 217.87 & 43.40 & 346.39 & 8.35 & 10.29 & 4.1 \\
\hline 2009 & 1365 & 1.21 & 497.95 & 273 & 346.71 & 241.60 & 35.58 & 379.47 & 10.9 & 11.17 & 3.9 \\
\hline 2010 & 1708 & 1.23 & 623.42 & 375.76 & 449.20 & 310.85 & 27.39 & 464.57 & 12 & 13.61 & 3.5 \\
\hline 2011 & 1816 & 1.24 & 718.77 & 444.92 & 564.77 & 335.96 & 36.49 & 590.2 & 8.86 & 14.92 & 3.5 \\
\hline
\end{tabular}

*Foreign Direct Investment

GDP, Population, Investment, Export, Import, Agriculture, FDI, Industry, R\&D: Billion US \$

Inflation: consumer prices (annual \%)

Unemployed :( \% of total labor force)

Sources: World Data Bank, IMF Cross Country Macroeconomic Statistic, World Bank National Accounts Data and OECD National Accounts Data Files, IMF Balance of Payments Database, IMF International Financial Statistics and Data Files, World Bank United Nations Educational, Scientific, and Cultural Organization (UNESCO) Institute for Statistics, International Labor Organization, Key Indicators of Labor Market Database.

With regression of ten independent variables on dependent variable GDP, it was found that there is very high correlation between these 11 variables and the correlation coefficients of them almost is high and all of correlation coefficients are positive except Unemployed that is negative which are shown in Table 12. 
Table 12

Correlation Coefficients*

\begin{tabular}{cccccccccccc}
\hline & GDP & Unemployed & R\&D & Population & Invest & Inflation & Industry & Import & FDI & Export & Agriculture \\
\hline GDP & 1.00 & -0.72 & 0.99 & 0.97 & 0.99 & 0.89 & 0.99 & 0.99 & 0.86 & 0.99 & 0.99 \\
Unemployed & -0.72 & 1.00 & -0.69 & -0.65 & -0.72 & -0.59 & -0.71 & -0.69 & -0.48 & -0.69 & -0.75 \\
R\&D & 0.99 & -0.69 & 1.00 & 0.97 & 0.99 & 0.89 & 0.99 & 0.99 & 0.88 & 0.99 & 0.99 \\
Population & 0.97 & -0.65 & 0.97 & 1.00 & 0.97 & 0.86 & 0.96 & 0.96 & 0.88 & 0.97 & 0.95 \\
Invest & 0.99 & -0.72 & 0.99 & 0.97 & 1.00 & 0.86 & 0.99 & 0.99 & 0.84 & 0.99 & 0.99 \\
Inflation & 0.89 & -0.59 & 0.89 & 0.86 & 0.86 & 1.00 & 0.84 & 0.86 & 0.85 & 0.86 & 0.88 \\
Industry & 0.99 & -0.71 & 0.99 & 0.96 & 0.99 & 0.84 & 1.00 & 0.99 & 0.85 & 0.99 & 0.99 \\
Import & 0.99 & -0.69 & 0.99 & 0.96 & 0.99 & 0.86 & 0.99 & 1.00 & 0.88 & 0.99 & 0.98 \\
FDI & 0.86 & -0.48 & 0.88 & 0.88 & 0.84 & 0.85 & 0.85 & 0.88 & 1.00 & 0.87 & 0.83 \\
Export & 0.99 & -0.69 & 0.99 & 0.97 & 0.99 & 0.86 & 0.99 & 0.99 & 0.87 & 1.00 & 0.98 \\
Agriculture & 0.99 & -0.75 & 0.99 & 0.95 & 0.99 & 0.88 & 0.99 & 0.98 & 0.83 & 0.98 & 1.00 \\
\hline Calculaty
\end{tabular}

*Calculated by Eviews

When we regressed all these 10 independent variables on GDP, prob (F-statistic) was equal to 0.01. It means that all of these independent variables effect on GDP, whereas p-value for every variable is over than 0.05 . As a result, for knowing about the coefficient of those 10 variables on GDP in India, we regressed them one by one and calculate the coefficient of them on GDP. Table 13 shows the coefficient and $p$-value of ten independent variables on dependent variable GDP.

Table 13

Coefficient and P-Value of Ten Independent Variables on Dependent Variable GDP

\begin{tabular}{|c|c|c|c|c|c|c|c|c|c|c|}
\hline & $\mathrm{R} \& \mathrm{D}$ & Import & Export & Investment & FDI & Industry & Agriculture & Inflation & Population & Unemployed \\
\hline Coefficient & 116.54 & 2.82 & 3.63 & 2.28 & 27.02 & 3.12 & 5.95 & 141.52 & 7123.96 & -1101.29 \\
\hline P-Value & 0.00 & 0.00 & 0.00 & 0.00 & 0.00 & 0.00 & 0.00 & 0.00 & 0.00 & 0.00 \\
\hline
\end{tabular}

In EViews calculation it was found out that every independent variable has signified effect on GDP, p-value for all of them is less than .05, and prob for all of them is also near zero. Nine independent variables positively effect on GDP but Unemployed coefficient is negative and it negatively effect on GDP.

Table 14

\begin{tabular}{lccc} 
India & & & \\
\hline Population & 1.31 billion & 2015 & India is the world's largest \\
GDP & $\$ 2.074$ trillion & 2015 & democracy and now emerged as \\
GDP growth & $7.6 \%$ & 2015 & a global player \\
Inflation & $5.9 \%$ & 2015 & \\
\hline
\end{tabular}

Source: World Data Bank

Level of income in India is lower than middle income, and India is called "lower-middle income country" in south Asia. Economy of India is at $3^{\text {rd }}$ in PPP (GDP) and $7^{\text {th }}$ in nominal (GDP) ranking; this ranking is based on projection by IMF outlook April 2015. Table 15 and Table 16 present the top ten countries in nominal (GDP) and top ten countries in PPP (GDP), respectively. 
Table 15

Top Ten Countries in Nominal (GDP)

\begin{tabular}{cc}
$1^{\text {st }}$ & United States \\
$2^{\text {nd }}$ & China \\
$3^{\text {rd }}$ & Japan \\
$4^{\text {th }}$ & Germany \\
$5^{\text {th }}$ & United Kingdom \\
$6^{\text {th }}$ & France \\
$7^{\text {th }}$ & India \\
$8^{\text {th }}$ & Brazil \\
$9^{\text {th }}$ & Italy \\
$10^{\text {th }}$ & Canada \\
\hline
\end{tabular}

Source: International Monetary Fund-World Economic Outlook (October -2015)

Table 16

Top Ten Countries in PPP (GDP)

\begin{tabular}{cc}
$1^{\text {st }}$ & China \\
$2^{\text {nd }}$ & United States \\
$3^{\text {rd }}$ & India \\
$4^{\text {th }}$ & Japan \\
$5^{\text {th }}$ & Germany \\
$6^{\text {th }}$ & Russia \\
$7^{\text {th }}$ & Brazil \\
$8^{\text {th }}$ & Indonesia \\
$9^{\text {th }}$ & United Kingdom \\
$1^{\text {th }}$ & France \\
\hline
\end{tabular}

Source: International Monetary Fund-World Economic Outlook (October -2015)

\section{Discussion and Conclusion}

New world has been established based on innovation; following this, fostering the talents and abilities and steering them towards the productive sectors of societies can promote the economic growth and development and can help the efficient use of production resources. Moreover, only funding for research and development is not enough; to this end, raising talents and making optimal use of human and non-human resources and guiding and managing these resources towards infrastructure production of societies can be helpful in economic development, social welfare, enhancing the lifestyle, and reducing the poverty and social gap. In countries that have put more emphasis on research and development and are depended on economy based on planning and finding new ways to optimize all resources including human and non-human resources, they could effectively pass the economic development and poverty reduction processes and enhance the social welfare.

During the years, the style of economic programs in the world has changed; the latest finding is to invest more on R\&D to find new and better ways to execution and best beneficiary of resources in the world to increase the development and decrease the gaps between developed and developing countries, improve welfare and style of living, and decrease poverty. Although there are many restraints in the world, but the dimension of beneficiary of research and the development of R\&D fund in the macro and micro economic programs depends on the ability to use talents, foster the innovation, and manage them for constructing their communities. The reason that some countries could not absorb new talents 
and innovation, may be due to the rise of immigration to other countries or development of social harms in countries.

Some countries like China or India could have remarkable growth during a short time. Japan is one of the developed countries without having many resources but with using programs and encouraging intelligence, they could improve their country, whereas many countries are not able to improve their economics and lose their wealth and valuable resources. These points are considered as the reasons why there is a huge gap between countries in the world.

\section{References}

Brookings Global Experts. (2007). Top 10 global economic challenges facing America's $44^{\text {th }}$ president. Washington, DC: The Brookings.

Deaton, A. (2015). Consumption, poverty and welfare. Stockholm: The Royal Swedish Academy of Sciences.

Greiner, A., Semmler, W., \& Gong, G. (2005). The forces of economic growth: A time series perspective. Princeton, NJ: Princeton University Press.

Elms, D., \& Low, P. (2013). Global value chains in a changing world. WTO: Fung Global Institute, Temasek Foundation Center for Trade and Organization.

Jaruzelski, B., Staack, V., \& Goehle, B. (2014). Global Innovation 1000: Proven Paths to Innovation Success. Strategy \& Business, 77, 1-16.

Low, P. (2013). The role of services in global value chains. In D. Elms \& P. Low (Eds.), Global value chains in a changing world. Geneva: World Trade Organization.

Percentages of people below poverty line. (2012). Rerieved from https://en.wikipedia.org/wiki/Poverty_in_India

Tirole, J. (2014). Market power and regulation. Stockholm: The Royal Swedish Academy of Sciences.

Brooking Global Experts. (2007). Top 10 global economic challenges facing America's $44^{\text {th }}$ president. Washington, DC: The Brookings. 